\title{
Risk Management and the Financial Performance of Banks in Nigeria
}

\author{
Henry Inegbedion ${ }^{1}$, Bello Deva Vincent ${ }^{2} \&$ Eseosa Obadiaru ${ }^{3}$ \\ ${ }^{1}$ Department of Business Studies, College of Business and Social Sciences, Landmark University, Omu Aran, Kwara \\ State, Nigeria \\ ${ }^{2}$ Department of ManagementTechnology, Modibbo Adama University of Technology Yola, Adamawa State, Nigeria \\ ${ }^{3}$ Department of Accounting and Finance, College of Business and Social Sciences, Landmark University, Omu Aran, \\ Kwara State, Nigeria \\ Correspondence: Dr Henry Inegbedion, Department of Business Studies, College of Business and Social Sciences, \\ Landmark University, Omu Aran, Kwara State, Nigeria.
}

Received: January 18, 2020

Accepted: February 23, 2020

Online Published: September 21, 2020

doi:10.5430/ijfr.v11n5p115

URL: https://doi.org/10.5430/ijfr.v11n5p115

\begin{abstract}
The study examined "risk management and financial performance of banks in Nigeria" with focus on commercial banks. The broad objective of the study was to ascertain the effect of risk asset management on the optimal financial performance of commercial banks in Nigeria.

The study is a longitudinal survey, so the ex-post facto research design was applied. Research data were analysed using generalized method of moments (GMM) and vector Error Correction Model, after testing and adjusting the data for stationarity and Cointegration.

The research findings were: Banks' profitability is significantly influenced in the short run by liquidity risk and in the long-run by credit risk, capital adequacy risk, leverage risk and liquidity risk. Furthermore, profitability measured by ROaA was found to be positively related to liquidity risk but negatively related credit risk. Arising from the findings, there is the need for effective risk management, especially credit, capital adequacy, leverage and liquidity risks, to enhance the profitability of banks. By helping to enhance the going concern of banks, risk management will help to reduce retrenchment and unemployment and hence help to forestall the attendant social vices.
\end{abstract}

Keywords: risk, credit risk, liquidity risk, capital adequacy risk, profitability and risk management

\section{Introduction}

A clear understanding of the various roles that banks play in a country's financial system is fundamental to theoretical economics and finance. The banking system provides a medium through which funds are withdrawn from those who have excess and channelled to deficit units of the system. The efficiency of the financial intermediation process is crucial for growth and general welfare (Allen \& Carletti, 2006). Commercial banks are a part of this process. Lenders of funds are primarily "households and firms. These lenders can supply funds to the ultimate borrowers who are mainly firms, governments and households; through financial markets which consist of money markets, bond markets and equity markets and through banks and other financial intermediaries such as money market, mutual funds, insurance companies and pension funds" (Allen \& Carletti 2006). Thus, one of the major roles of Banks in the financial system is that of financial intermediation.

Commercial banks create credit through the fractional reserve system. The total amount of money that can be created in a fractional reserve system is equal to reserves times the deposit multiplier (Mankiw 2008). One of the services that commercial banks render to their numerous customers is lending. They perform this function "bearing in mind the three principles guiding their operations; which are, profitability, liquidity and solvency" (Olokoyo 2011, 61). When banks pay interest on deposits and receive interest on loans, the difference between the two interest rates constitutes their profit on deposits. Banks can only leverage this profit if the borrowers pay back their loans. However, there is a likelihood that some proportion of the loans may not be paid back; this underscores the need for risk management, especially credit risk management. The management of credit risk is perceived to be instrumental to the minimization of the incidence of bad debts because bank credit which is aimed at enhancing profitability has precipitated the incidence of bad debts in Nigerian banks owing to the inadequate management (Uwalomwa, Uwuigbe \& Oyewo, 
2015).

Risk management seeks to quantitatively improve the measurement and management of specific risks such as liquidity, leverage, market, financial, solvency and credit risks. To this end, this study examines the effect of risk management on the performance of financial institutions in Nigeria with a focus on Commercial banks.

\subsection{Purpose of the Study}

This study sought to ascertain the effect of risk management on the optimal performance of commercial banks in Nigeria. The specific objective was to determine the extent of the relationship between a Commercial bank's profitability and risks (leverage risk, credit risk, liquidity risk and capital adequacy risk).

\subsection{Justification of the Study}

Banks have to cope with various risks in the course of their operations. In addition to other risks, credit risk is faced by all commercial banks because a bank cannot remain in business if it neglects the credit function (Osayeme 2000); besides, banks' loan portfolio is part of the various sources of income that accrue to them. Poor or inadequate credit risk has been reputed to be the Achilles hill of many commercial banks because it is responsible for the growing increase in the proportion of non-performing loans in their loan portfolio. Adeusi, Akeke, Adebisi and Oladunjoye (2013) have argued that an entrenchment of sound risk management framework is sacrosanct to the competitiveness of commercial banks. It is thus evident that proper risk management is essential to the survival and competitiveness of commercial banks.

\section{Literature Review}

\subsection{Risk and Financial Distress}

A major reason that banks need to manage risk is to forestall financial distress, a likely consequence of risk. Banks need to be financially viable in order to succeed in their business of financial intermediation. Managers are more than ever before having an obligation to meet up with their responsibilities and optimise the wealth of shareholders. This has assumed monumental importance because, owing to the short-medium term financial intermediation carried out by banks (being intermediaries between lenders and borrowers), a shortage in liquidity can lead to adverse effects on their ability to meet up with the demands of customers. This can precipitate financial distress, which refers to a bank`s inability to fulfil its financial obligations to depositors or fulfil the same with difficulty (Arnold, 2008). "Financial distress arises when a bank starts experiencing financial problems that may force it to close, merge with another bank, declare bankruptcy, eliminate services, or take actions that have adverse effects on the financial service delivery system of a region" (Trussel \& Patrick, 2009, 39).

The consequences of financial distress on banks are, to say the least, detrimental; owing to the likelihood of protracted negative consequences associated with the narrowing of the margin between cash flows and debt servicing by such distress when they occur (Ogden, Jen \& O’Connor, 2002). Loss of confidence, especially if the customers suspect the likelihood of the bank going bankrupt in the near future, loss in shareholders' value; loss of motivation of employees in an unhealthy firm arising from perceived increase in employee job insecurity and inadequate likelihood of advancement in the wake of the consequences of financial distress are some of the consequences of financial distress, among others.

\subsubsection{Risk Management and Financial Performance of Banks}

Performance is synonymous with well doing or otherwise and financial performance is synonymous with financial well doing. More succinctly, "financial performance is a subjective measure of how well a firm can use assets from its primary mode of business to generate revenues; it refers to a firm's overall financial health over a given period" (Bhunia et-all, 2011, 269). Often times, it is instructive to analyse the financial performance of a firm to get a clear picture of the firm's financial well doing. Financial performance analysis reveals a firm's operating and financial characteristics from its financial statements; "the goal of such analysis is to determine the efficiency and performance of firm's management, as reflected in the financial records and reports" (Bhunia, Mukhuti \& Roy 2011, 269). For a bank to succeed in its statutory operations, strategic managers of such banks must examine the trade-offs between organisational growth, returns and risks favouring the adoption of risk-adjusted metrics (Ralph \& Kimball, 1998). Banks` performance can be classified into traditional, economic and market-based (Agbeja, Adelakun \& Olufemi, 2015). Since all bank risks, whether liquidity, capital adequacy or credit risks, precipitate liquidity problems; effective risk management will ensure that banks are able to leverage optimum liquidity and hence enhance profitability and investments to optimise shareholders wealth. Effective risk management will also help to enhance service delivery and customer loyalty (Inegbedion \& Obadiaru, 2018). 


\subsection{Theoretical Framework}

Financial risks have been known to exert substantial influence on the stability of the banking system performance. This underscores the need "to measure and control the determinants of financial risk, especially at the aggregated level" (Misker, 2015, 11). Three theories that seek to explain the influence of financial risk on banks' performance are presented below.

\subsubsection{Commercial Loan Theory}

The major thrust of this theory is that banks should lend only on short-term, self-liquidating basis. The theory is popular among commercial banks in Nigeria because Nigerian bankers are of the view that bank deposits should be employed in short-term loans since they are repayable at short notice. The theory has some shortcomings. The major shortcoming is its insistence that all loans should be liquidated in the normal course of business; a development that indicates its incognisance of the relative stability of bank deposits. The stability of bank deposits implies that notwithstanding the fact that demand deposits are on demand, only a fraction of depositors often demand for payment at a given time, except there are indications that the bank is threatened. The stability of deposits makes it possible for a bank to lend a fraction of the deposits for a reasonably long period without danger of illiquidity. Despite the shortcomings of the commercial loans theory, it has prevailed overtime in banking and vestiges of it still find relevance in the thinking of many stakeholders in the banking industry.

\subsubsection{Credit Risk Theory}

Credit risk is the likelihood that a customer to whom the bank has extended credit may not pay on time or may not pay at all (default). Primarily, credit risk is that of the lender and it consists of lost principal and interest. One of the ways to manage credit risk is by subjecting prospective borrower (s) to extensive credit checking to determine their credit worthiness. This may necessitate an insurance policy on the part of the borrower. In general, risk is directly proportional to interest rate that the borrower is made to pay, which implies that the higher the risk, the higher the interest rate that the borrower will be requested to pay on the debt (Owojori, Akintoye \& Adidu, 2011).

\subsubsection{Shiftability Theory}

This theory is reputable for its preference for the marketability of bank assets. "It recognizes decreasing significance of short term self-liquidating loan. The theory recognizes and contends that shiftability, marketability or transferability of a bank's assets is a basis for ensuring liquidity" (Ikeora \& Werigbelegha, 2016; and Kamunosiki, Giami \& Obari, 2017) and that the marketability of a bank security is liquidity in disguise.

\subsection{Empirical Review}

Okere, Isiaka and Ogunlowore (2018) investigated "Risk management and financial performance of deposit money banks in Nigeria" to ascertain the impact of credit and liquidity risk management on the financial performance of deposit money banks (DMBs) in Nigeria. They employed longitudinal survey, using panel data, and analysed the data with Hausman test and other econometric techniques. Risk management was found to be positively related to the financial performance of DMBs. Olusanmi, Uwuigbe and Uwuigbe (2015) investigated "the effect of risk management (RM) on bank's financial performance (FP) in Nigeria." The study employed longitudinal research design and secondary data which were sourced from the sampled banks' financial statements. Ordinary least squares technique was employed in analysing the data. RM was found not to be significantly related to bank performance.

Olaleye and Wan (2016) reviewed literature on RM and the FP of commercial banks in Nigeria to ascertain the relationship between RM practices and bank FP in Nigerian banking industry. Specifically, the authors sought to study the influence of risk management on the financial performance of banks. Their review indicates that poor risk management stunts profitability and by implication, hinders organisational growth. Chukwunulu, Ezeabasili and Igbodika (2019) studied the effect of RM on bank FP in Nigeria. They employed longitudinal design and analysed the research data using least squares method. Credit risk was found to significantly (negatively) influence return on equity but the negative relationship with return on assets was insignificant. Furthermore, liquidity management and operational risk had no significant effect on bank performance but capital adequacy is significantly positively related to ROE and insignificantly related to return on assets.

Etale and Ujuju (2018) investigated "risk management, risk concentration, and the performance of deposit money banks (DMBs) in Nigeria". Credit, liquidity and capital adequacy risks were used to measure RM/concentration while ROA was used to measure performance. Longitudinal research design was employed and data were collected from the financial statements of listed banks. Least squares technique was used to analyse data. Credit and liquidity risks were found to have significant effect on banks' performance in Nigeria. 
Lasisi, Lateef, Irom and Bulus (2018) studied "corporate board size, risk management, and financial performance of listed DMBs in Nigeria". The sample size consisted of fourteen (14) listed DMBs in Nigeria. Number of board directors was used to measure board size (BS) while ROE and EPS were used to measure financial performance. Least squares technique was employed on the panel data. BS, credit risk and operating risk were found to be significantly related to banks' performance. Nwude and Okeke (2018) examined "the impact of credit risk management (CRM) on the performance of selected DMBs in Nigeria" using five banks based on highest asset base. The study employed Ex-post facto research design and secondary data of the relevant ratios of the selected DMBs. OLS was used to analyse the data. Credit risk management was found to be significantly related to total loans and advances as well as the ROA and ROE of DMBs. Akinselure and Akinola (2019) investigated "the impact of CRM on profitability of selected DMBs in Nigeria." A longitudinal study of 13 deposit money banks was employed. The data were analysed using multiple regression. Credit management was found to be significantly related to the profitability of the DMBs.

Ezelibe and Aniefor (2017) investigated "financial risk management and corporate performance of DMBs in Nigeria." Longitudinal survey design was employed and secondary data were extracted from records of the fifteen sampled listed DMBs. RM was measured by bank size (BSZ) while corporate performance was measured by (ROE). Simple regression technique was employed in data analysis. It was found that BSZ has insignificant effect on the ROE of DMBs in Nigeria within the period studied. Oyedele, Adeyemi and Fasesin (2018) examined "CRM and its effect on the FP of banks" with focus on selected banks in Nigeria. They used purposive sampling to select five Nigerian banks and extracted secondary data from the financial statements of the banks to compute the relevant financial ratios (ROA and ROE), loans to deposit ratio (LTDR), and capital adequacy risk (CAR) served as the study's main variables. Regression analysis was performed on the data. LTDR was found to be significantly related to ROA. CAR and LTDR were also found to be significantly positively related to ROE but NLPR was found to have a negative and significant influence on ROE. They thus concluded that the banks' CRM had a significant influence on their FP. Ironkwe and Osaat (2019) investigated "risk asset management and FP of insurance companies in Nigeria." Secondary data on the relevant variables were obtained from the database of the Central Bank of Nigeria. ROA, ROE and leverage risk were then computed and used to estimate the long and short-run relationship as well as causal effects. Data were analysed using multiple regression. Unit root test was performed to test for stationarity. Leverage risk was found to be significantly related to return on equity. The results were found not to be consistent with a priori expectations.

Kegninkeu (2018) examined "the impact of credit risk management on the performance of commercial banks in Cameroon with focus on BICEC" and to evaluate loan assessment techniques and various risk management techniques employed by the banks in credit risk management. The research design was longitudinal survey and secondary data were used to conduct ratio and trend analyses. Non-Performing loans (NPL) ratio and loan to total deposit ratio were found to be significantly related to bank financial performance. Olajide and Fadun (2017) investigated "corporate governance in the companies listed on the floor of the Nigeria Stock Exchange (NSE)" to ascertain the extent to which it enhances RM and FP of firms to optimise stakeholders' interest. Thirty listed companies as at 2016 were used. Board size (BS), board independence (BI) and CEO Duality/Tenure (D/T) were the explanatory variables studied while ROA and ROE served as performance indicators. The longitudinal survey research design was used and secondary data were employed. Results showed that BS and BI were positively correlated with firm performance but CEO tenure was negatively correlated with firm performance.

Vadova (2005) examined credit risk as a cause of banking crisis. He observed that inadequate RM was a root cause of banking crisis.

Kolapo, Ayeni, and Oke (2012) investigated "the influence of credit risk on the performance of commercial banks in Nigeria within the period 2000-2010." Cross-sectional survey design was employed on five sampled banks. The results show that credit risk has a cross- sectional effect on bank performance but the effect is invariant with the type of bank. The implication is that the cross-sectional effect of credit risk on bank performance is similar across all the banks in Nigeria not minding the omission of the degree of influence on individual banks by the analytical technique employed.

Adeusi et-al (2013) investigated RM and FP of banks in Nigeria. They employed secondary data based on ten selected DMBs for a period of four years. Panel data was employed and least squares estimation served as the method of data analysis. The results show that financial performance of banks was negatively related to doubtful loans. Consequently, they concluded that banks` financial performance is significantly related to risk management.

Obalola, Akpan and Abass (2014) investigated the extent to which the management of integrated risks (strategic, 
systemic and reputational), "through enterprise risk management (ERM), can enhance organizational performance in Nigerian Insurance industry. Purposive sampling technique was used to select ten insurance companies for the study." They utilised panel data on a cross-section of the ten organisations for a period of ten years, from 2001 to 2010. ERM was found to significantly influence organizational performance. Based on the findings, they recommended the need for the insurance industry in Nigeria to adopt ERM practice.

\subsubsection{Gap in Literature}

There is abundant literature related to RM and FP in DMBs in Nigeria. They include: RM and FP of DMBs in Nigeria (Chukwunulu, Ezeabasili \& Igbodika, 2019; Okere, Isiaka \& Ogunlowore, 2018; Ezelibe \& Aniefor, 2017; Olaleye \& Wan, 2016; Olusanmi, Uwuigbe \& Uwuigbe, 2015; and Etale \& Ujuju, 2018), BS, RM, and FP of listed DMBs in Nigeria (Lasisi, Lateef, Irom \& Bulus, 2018); Impact of CRM on the performance of selected DMBs in Nigeria (Nwude \& Okeke, 2018; Akinselure \& Akinola, 2019; Oyedele, Adeyemi \& Fasesin, 2018; Kegninkeu, 2018), risk asset management and FP of insurance companies in Nigeria (Ironkwe \& Osaat, 2019) and corporate governance in the companies listed on the floor of the Nigeria Stock Exchange (Olajide \& Fadun, 2017). Majority of the studies found that: RM is significantly related to the FP of DMBs (Oyedele, Adeyemi \& Fasesin, 2018; Okere, Isiaka \& Ogunlowore, 2018; Olaleye \& Wan, 2016), credit risk significantly influences profitability (Chukwunulu, Ezeabasili \& Igbodika, 2019; Etale \& Ujuju, 2018), Board size, credit risk and operating risk have significant negative effect on financial performance (Lasisi, Lateef, Irom \& Bulus, 2018) and credit risk management has a positive and significant impact on total loans and advances and the ROA and ROE of deposit money banks (Nwude \& Okeke, 2018). However, most of these studies concentrated on credit risk and liquidity risk as the majors concerns of banks and thus examined risk management from the point of view of liquidity and credit risk management. Given that the principles guiding bank operations are, profitability, liquidity and solvency, the authors of this article believe that the exclusion of solvency risk from the previous studies is a significant omission. The desire to bridge this gap in knowledge formed the basis of this study.

\section{Methodology}

This section presents the research design, measurement of variables, model specification and the method of data analysis

\subsection{Design}

The design was a longitudinal study of the financial performance indicators of commercial banks in Nigeria using Access bank, Diamond Bank, Guarantee Trust Bank, First Bank and Zenith Bank as focus. Since the study relied solely on secondary data, all the data requirements were obtained from the relevant secondary sources. Specifically, the secondary data used were the annual reports of Access Bank, Diamond Bank, GT Bank, First Bank and Zenith Bank for the period 2010 - 2017. Thus, a panel data of 5 cross sections for 8 years was employed. The key information include Earnings after Tax, loans and advances, non-performing loans, total assets, equity, total deposits, current assets, current liabilities and net sales, which are all integral components of the financial statements. From these, liquidity, loans to deposit, capital adequacy, non-performing and profitability ratios were computed.

\subsection{Measurement of Variables}

Financial performance of banks is measured by return on average assets (ROaA) and return on average equity (ROaE). Three major risk indicators were used; the risk indicators and their proxies (ratios) are: Liquidity risk (loans to deposit and current ratio), credit risk (Non-performing loans ratio) as well as leverage risk (capital adequacy ratio). Leverage risk was measured by capital adequacy ratio because capital inadequacy is stimulated by excess leverage.

\subsection{Model Specifications}

The model specifications of this study are as follows:

$\mathrm{ROaA}=\mathrm{f}(\mathrm{LDR}, \mathrm{CR}, \mathrm{CAR}, \mathrm{NPLR})$ and

$\mathrm{ROaE}=\mathrm{f}(\mathrm{LDR}, \mathrm{CR}, \mathrm{CAR}, \mathrm{NPLR})$

Specifically, the model Equations are:

$$
\begin{gathered}
\mathrm{ROaA}=\mathrm{bo}+\mathrm{b}_{1} \mathrm{LDR}+\mathrm{b}_{2} \mathrm{CR}+\mathrm{b}_{3} \mathrm{CAR}+\mathrm{b}_{4} \mathrm{NPLR} \mathrm{e}_{1} \\
\mathrm{ROaE}=\alpha_{0}+\alpha_{1} \mathrm{LDR}+\alpha_{2} \mathrm{CR}+\alpha_{3} \mathrm{CAR}+\alpha_{4} \mathrm{NPLR}_{+} \mathrm{e}_{\mathrm{t}}
\end{gathered}
$$

Where

$\mathrm{ROaA}=$ return on average assets (Profitability) 
$\mathrm{ROaE}=$ return on average equity (Profitability)

$\mathrm{LDR}=$ loans to deposit ratio

$\mathrm{CR}=$ Current ratio

$\mathrm{CAR}=$ Capital adequacy ratio

NPLR = non-performing loans ratio (credit risk)

$\mathrm{b}_{0}=$ proportion of the change in return on average Assets ( $\left.\mathrm{ROaA}\right)$ that is not explained by changes in the explanatory variables, LDR, CR, CAR and NPLR

$b_{1}=$ Slope of LDR; $b_{2}=$ Slope of CR; $b_{3}=$ slope of CAR and $b_{4}=$ slope of NPLR and $e=$ random error.

Also $\alpha_{0}=$ proportion of the change in return on average equity (ROaE) that is not explained by changes in the explanatory variables, LDR, CR, CAR and NPLR

$\alpha_{1}=$ Slope of LDR; $\alpha_{2}=$ Slope of CR; $b_{3}=$ slope of CAR and $b_{4}=$ slope of NPLR.

\subsection{Method of Data Analysis}

Bearing in mind that the efficacy of any Time Series analysis is conditioned on stationarity of the data; the research data were adjusted for stationarity. Specifically, since most non-stationary time series data become stationary after integrating them once (Engel \& Granger, 1987; Iyoha \& Ekanem, 2004; Inegbedion, Obadiaru \& Adeyemi, 2020), the variables were tested for panel stationarity using the augmented Dickey Fuller test and the two dependent variables were stationary at level while all the independent variables were stationary at first difference. Panel cointegration test was further carried out using Johansen`s technique and the variables were found to be cointegrated. Arising from the model specification, generalized method of moments (GMM) was used to analyze the research data owing to its suitability in the context of semi parametric models for finite-dimensional parameters whose distribution function are unknown.Vector error correction modeling was also employed following the long run relationship between the variables revealed by the results of the cointegration test. Data analysis was performed using Eviews software.

\section{Results}

The panel PP statistic had a calculated value of -5.095 and a significant probability of $\mathrm{P}<0.001$, thus indicating that the null hypothesis of no cointegration be rejected at the $99 \%$ level of confidence. The implication is that a long run relationship exists between financial performance of commercial banks in Nigeria (measured by ROaA and ROaE) and the risk factors - liquidity, leverage, capital adequacy and leverage. (see Table 1)

Table 1. Cointegration Test

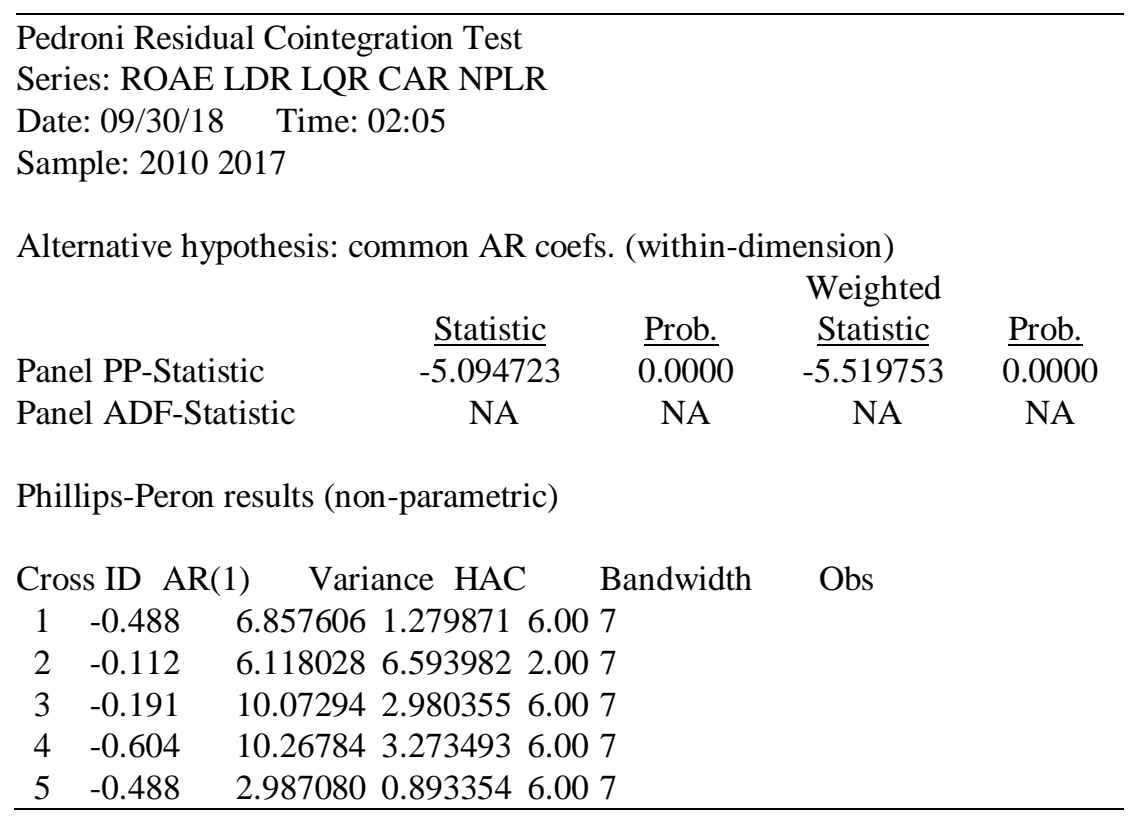


Results of the GMM test of financial performance (using ROaA) and risk factors show that the calculated Durbin-Watson statistic is 1.6, which is within the permissible range of du-4-du for "no serial correlation. The adjusted $\mathrm{R}$-square value is 0.483 thus suggesting that $48.3 \%$ of the variation in return on average assets is explained by variation in the explanatory variables (loans to deposit ratio, liquidity risk, capital adequacy risk and credit risk). Furthermore the $t$ test for significance of the model parameters shows that the calculated $t$ values and associated asymptotic significant probabilities were -0.04 [0.94]; -0.21 [0.83]; 3.01 [0.0047] and -3.53 [0.0011] for LDR, CR, CAR and NPLR respectively. The results indicate an inverse relationship between ROaA and three of the explanatory variables (Loans to deposit ratio, liquidity ratio, and Non-performing loans ratio) but only the Non-performing loans ratio was significant among the ratios that are inversely related to return on average assets. Furthermore, there is a direct relationship between ROaA and capital adequacy ratio; the direct relationship was significant (see Table 2).

Table 2. Return on average assets and financial risks

\begin{tabular}{|c|c|c|c|c|}
\hline $\begin{array}{l}\text { Dependent Variable: } \\
\text { Method: Panel Least } \\
\text { Date: 09/30/18 Ti } \\
\text { Sample: } 20102017\end{array}$ & $\begin{array}{l}\text { res } \\
1: 49\end{array}$ & & & \\
\hline Variable & Coefficient & Std. Error & t-Statistic & Prob. \\
\hline LDR & $-1.66 \mathrm{E}-05$ & 0.000236 & -0.070159 & 0.9445 \\
\hline LQR & -0.006003 & 0.028113 & -0.213547 & 0.8321 \\
\hline CAR & 0.166338 & 0.055241 & 3.011156 & 0.0047 \\
\hline NPLR & -0.209877 & 0.059386 & -3.534117 & 0.0011 \\
\hline R-squared & 0.483142 & Mean depend & t var & 1.861350 \\
\hline Adjusted R-squared & 0.440070 & S.D. depende & & 2.184282 \\
\hline S.E. of regression & 1.634465 & Akaike info $\mathrm{c}$ & erion & 3.915148 \\
\hline SS resid & 96.17312 & Schwarz crite & & 4.084035 \\
\hline Log likelihood & -74.30295 & Hannan-Quin & criter. & 3.976212 \\
\hline D-W stat & 1.59250 & & & \\
\hline
\end{tabular}

Results of the GMM test of financial performance (using ROaE) and risk factors show that the calculated Durbin-Watson statistic is 1.7, which is within the permissible range of du - 4-du for "no serial correlation. The adjusted R-square value is 0.38 .13 thus suggesting that $38.13 \%$ of the variation in return on average equity is explained by variation in the explanatory variables (liquidity risk, capital adequacy risk and credit risk). Furthermore the $\mathrm{t}$ test for significance of the model parameters shows that the calculated $\mathrm{t}$ values and associated asymptotic significant probabilities were -0.25 [0.81]; 2.03 [0.0496]; 0.89 [0.38] and -3.26 [0.0024] for liquidity risk (LDE, CR), leverage risk (CAR) and credit risk (NPLR) respectively. The results indicate an inverse relationship between ROaE and two of the explanatory variables (Loans to deposit ratio and Non-performing loans ratio) but only the Non-performing loans ratio was significant among the two ratios that are inversely related to return on average Equity. Furthermore, there is a direct relationship between ROaE and two of the explanatory variables, liquidity ratio and capital adequacy ratio but only the relationship between ROaE and Liquidity ratio was significant (see Table 3). 
Table 3. Return on average equity and financial risks

Dependent Variable: ROAE

Method: Panel Least Squares

Date: 09/30/18 Time: 01:51

Sample: 20102017

Periods included: 8

Cross-sections included: 5

Total panel (balanced) observations: 40

\begin{tabular}{lrlll}
\hline \multicolumn{1}{c}{ Variable } & Coefficient & Std. Error & t-Statistic & Prob. \\
\hline LDR & -0.000341 & 0.001385 & -0.246372 & 0.8068 \\
LQR & 0.334950 & 0.164821 & 2.032203 & 0.0496 \\
CAR & 0.289201 & 0.323866 & 0.892966 & 0.3778 \\
NPLR & -1.135163 & 0.348168 & -3.260390 & 0.0024 \\
\hline R-squared & 0.381319 & Mean dependent var & 14.16848 \\
Adjusted R-squared & 0.329762 & S.D. dependent var & 11.70488 \\
S.E. of regression & 9.582558 & Akaike info criterion & 7.452406 \\
Sum squared resid & 3305.715 & Schwarz criterion & 7.621294 \\
Log likelihood & -145.0481 & Hannan-Quinn criter. & 7.513470 \\
\hline
\end{tabular}

Results of the error correction model present the long run equilibrium relations. The first cointegration equation is estimated as: ROaA-1.682 - 0.227 LDR - 0.5493 CR + 0.225 CAR + 0.073NPLR = 0;

Thus, $\mathrm{ROaA}=1.682+0.227 \mathrm{LDR}+3.549 \mathrm{CR}-0.225 \mathrm{CAR}-0.073 \mathrm{NPLR}$

The second cointegration equation is estimated as:

ROAE-17.03 - 3.477 LDR - 1.512 CR + 3.47 CAR - 0.264NPLR = 0;

Thus, $\mathrm{ROAE}=17.03+3.477 \mathrm{LDR}+1.512 \mathrm{CR}+3.47 \mathrm{CAR}-0.264 \mathrm{NPLR}$

The results show that liquidity risk (LDR, CR), leverage risk (CAR) and credit risk (NPLR) are significant long-run predictors of ROaA and ROAE.

Following the long-run coefficients of the cointegration equations, we estimated the short-run coefficients through the Error correction model (ECM) component (see Table 4). The ECM Estimations in cointegration equation 1 show that the coefficients of all the regressors have the hypothesized (A priori) signs and one of the variables, CR, is statistically significant to ROaA and ROaE while three (LDR, CAR and NPLR) are not. CR is a significant sort-run predictor of both ROaA and ROaE at one per cent (1\%) level. Furthermore, the results of ECM show that the coefficients of LDR, CR and NPLR are negative while that of CAR is positive (see Table 5). The coefficients of the error correction terms (ECT) are -0.294 and -0.153 for ROaA and ROaE. Thus, the speed of adjustment after short-run deviation from the equilibrium is $29.4 \%$ for ROaA and $15.3 \%$ for ROaE. The value indicates the speed of restoration of the system to equilibrium after a previous deviation. The implication is that previous period disequilibrium is corrected at a speed of $29.4 \%$ and $15.3 \%$ for $\mathrm{ROaA}$ and $\mathrm{ROaE}$ respectively.

Lastly, results of the error correction model show that that the explanatory variables (LDR, CR, CAR and NPLR) explain about $42.15 \%$ and $27.31 \%$ of the variation in the dependent variables (ROaA and ROaE) as shown by the adjusted coefficients of variation. The adjusted R-square (coefficient of variation) values obtained in the error correction model are smaller than those obtained from the GMM test (48.31\% and 32.98). This is a result of the adjustments that were made by the error correction model to the initial data (see Table 4).

Table 4. Vector Error correction Model

Vector Error Correction Estimates

Date: 03/29/17 Time: 11:10

Sample (adjusted): 19842015

Included observations: 32 after adjustments

Standard errors in ( ) \& t-statistics in [ ] 


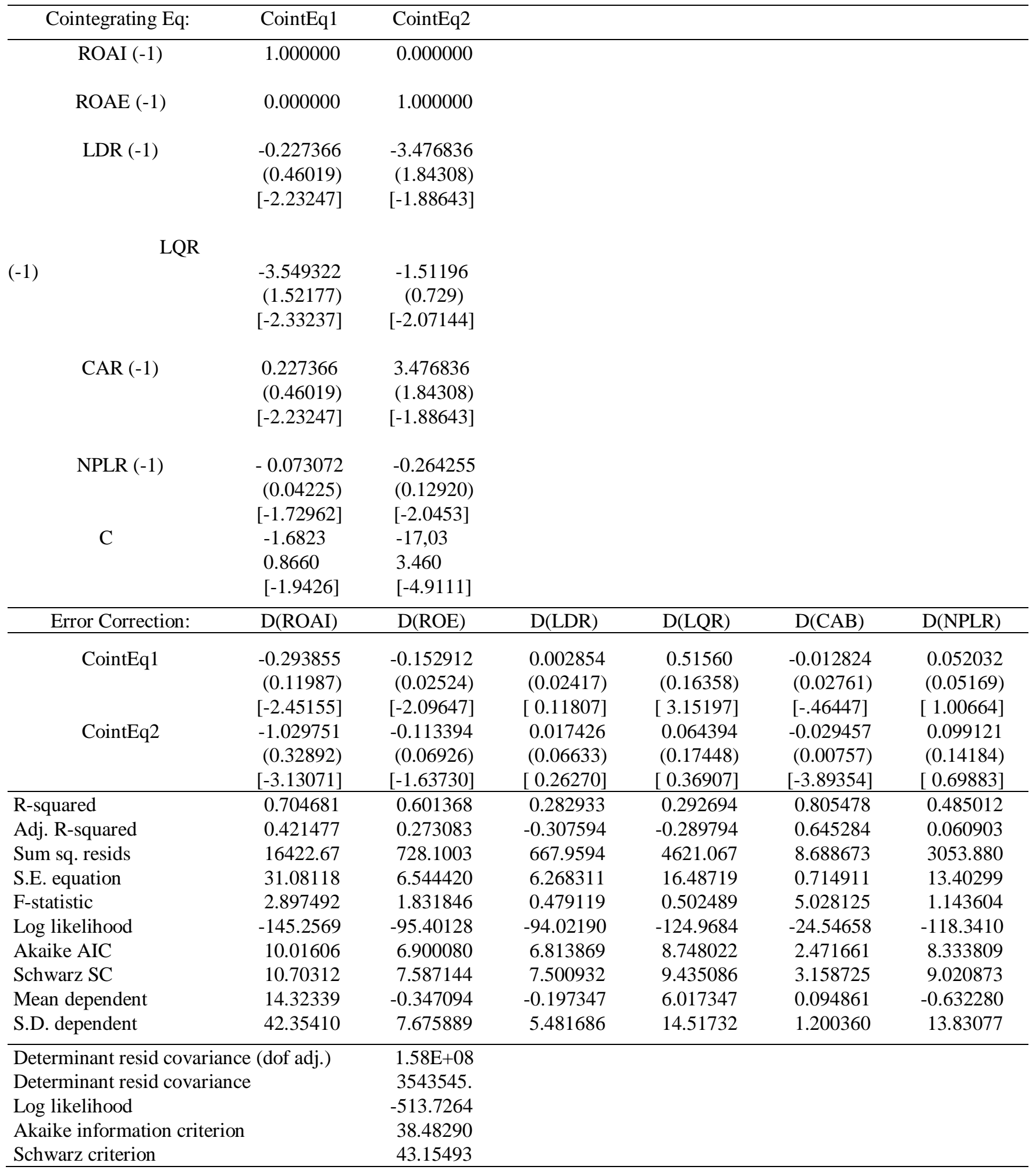

\subsection{Discussion of Findings}

The results indicate that there is significant inverse (negative) relationship between ROaA (dependent variable) and liquidity risks, leverage risk and credit risk and all the relationships were significant. The implication is that increases in credit risk leads to reduction in a bank's investible funds and hence reduction in its average assets. This is not 
unconnected with the fact that increases in a firm's credit risk reduce its liquidity and thus impact on its ability to acquire assets. The implication is that credit risk is very significant to ROaA. Also, increases in liquidity risk lead to reduction in a bank's investible funds and hence reduction in its average assets. There is also a significant positive relationship between ROaA and CAR. This implies that the more a bank is able to absorb the debt component of its capital structure through equity capital, the higher it is able to generate funds for investment in assets and hence adequate ROaA. The results are consistent with the findings of Oyedele, Adeyemi and Fasesin (2018), Okere, Isiaka and Ogunlowore (2018), Chukwunulu, Ezeabasili and Igbodika (2019), Etale and Ujuju (2018), Olaleye and Wan, 2016), Kolapo, Ayeni, and Oke (2012), Oluwafemi, Adebisi, Simeon and Olawale (2013) and Obalola, Akpan and Abass (2014)

The results further indicate that there is significant inverse (negative) relationship between ROaE (dependent variable) and liquidity risk and credit risk and the two relationships were significant; thus implying that increases in credit risk and liquidity risk lead to reduction in a bank's ability to reward equity shareholders and that liquidity risk and credit risk are very significant to ROaE. There is a significant positive relationship between ROaE and CAR. This implies that the more a bank is able to absorb the debt component of its capital structure through equity capital, the higher it is able to generate funds to reward equity shareholders. Again, the results are consistent with the findings of Oyedele, Adeyemi and Fasesin (2018), Okere, Isiaka and Ogunlowore (2018), Chukwunulu, Ezeabasili and Igbodika (2019), Etale and Ujuju (2018), Olaleye and Wan, 2016), Kolapo, Ayeni, and Oke (2012), Oluwafemi, Adebisi, Simeon and Olawale (2013) and Obalola, Akpan and Abass (2014)

A comparison of the panel GMM test with the ECM shows some slight differences. While the GMM shows that NPLR and CAR are predictors of ROaA, the ECM shows that LDR, NPLR, CAB and CR significantly influence ROaA in the long run while CR significantly influences it in the short run. On the other hand, GMM shows that NPLR and LQD have significant influence on ROAE while the ECM shows that LDR, CR, CAR and NPLR influence ROaE in the long run while only CR influences ROAE in the short run. Given the fact that ECM is applicable to time series analysis when the variables under investigation are cointegrated, the results of the ECM supersede those of the GMM. Again LDR does not influence financial performance in the long run while current ration does; this shows that not all facets of liquidity have a short-run influence on financial performance

\subsection{Proposed Model of Risk Management and Banks' Performance}

In view of the findings, a model of risk management and financial performance was suggested (see Figure 1). The model indicated that effective management of liquidity risk in the short run as well as management of credit risk, leverage risk, capital adequacy risk and liquidity risk in the long run is what banks require to enhance performance. The implication is that liquidity risk is critical to bank performance since its management is required in the short run and in the long run.

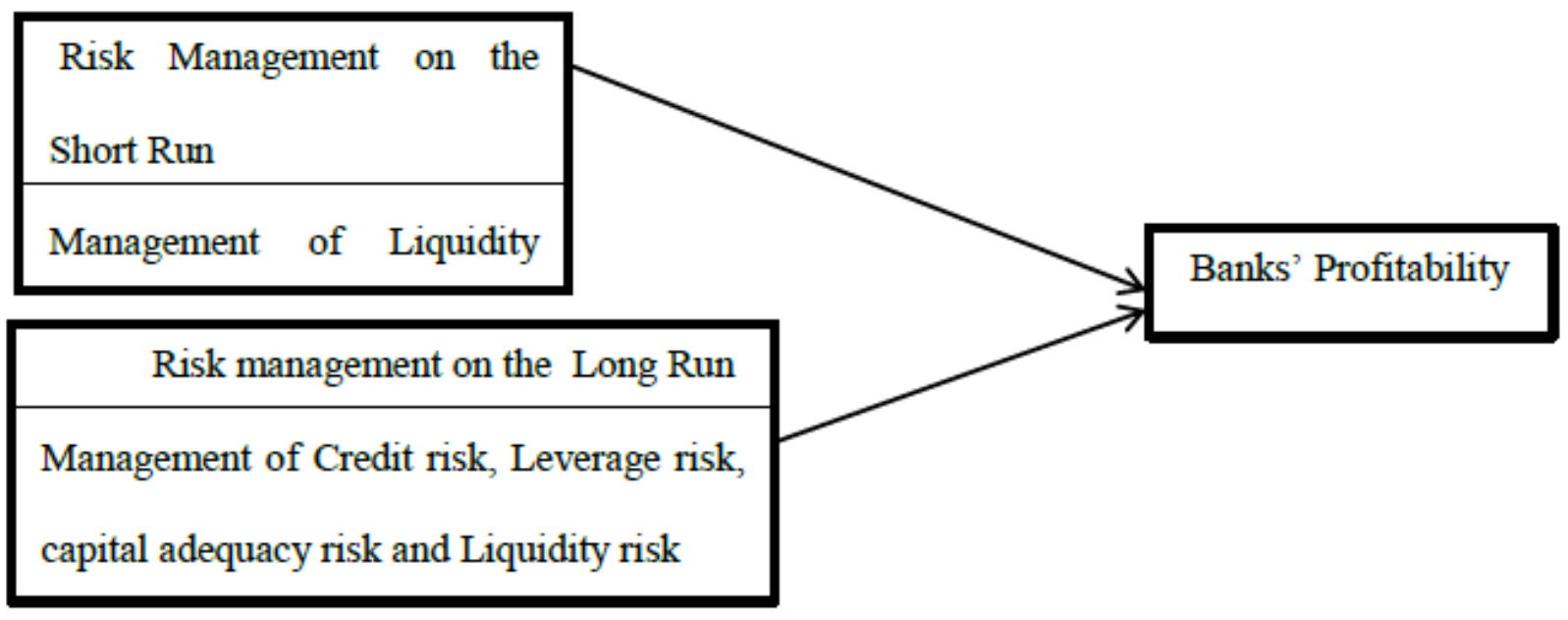

Figure 1. A Model of risk management and bank performance 


\subsection{Implication of Findings}

The results indicate the need for stakeholders to take cognisance of the short-term and long-term impact of liquidity risk (measured by current ratio) on financial performance (ROaA and ROaE) of banks as well as the long-term influence of solvency risks measured by LDR, CAR and NPLR on financial performance of banks. While a short-term effect may trigger technical insolvency, a long-term influence may precipitate bankruptcy directly or indirectly through a poorly managed state of technical insolvency. Due cognisance by concerned stakeholders will enable them take proactive steps towards risk management and prevent them from being taken unaware.

\section{Conclusion}

The research conclusions are: liquidity risk has significant short-term influence on financial performance of banks; Liquidity risk (current ratio and Loans to deposit ratio), levage risk (capital adequacy ratio) and credit risk (non-performing loans ratio) have significant long-run influence on financial performance. To this end, adequate risk management, especially management of liquidity risk, leverage risk and credit risk will serve to enhance financial performance in the banking sector

This study has made significant contribution to knowledge in management science and financial management literature. Although several studies have attempted to explain the relationship between risk management and financial performance of banks, the point of departure of this study from most previous studies is the conspicuous observation that while most of such studies identified relationships between financial performance and risk factors, it is doubtful if any of them segregated such effects into short run and long run effects. This study has been able to show that liquidity risk (measured by current ratio) has a short-term and long term influence on financial performance ( $\mathrm{ROaA}$ and $\mathrm{ROaE}$ ) of banks while leverage risk and credit risk have long run influence on financial performance of banks. Furthermore, most previous studies on the research problem employed least square method in data analysis, thus ignoring the short-run and long-run influence of the predictors. This study bridged this gap by employing vector error correction model. Lastly, this study showed that all facets of liquidity do not exert the same influence as seen in the long-run effect of loans to deposit ratio on financial performance while current ratio has short-run and long-run influence on financial performance.

The study is not without some limitations that suggest the need for further studies. The performance indicators (return on average assets and return on equity) as well as the risk proxies that served as explanatory variables (loans to deposit ratio, current ratio, capital adequacy ratio and non-performing loans ratio) included in the study were randomly selected from a host of financial performance indicators and risk factors. The extent to which these variables are or are not exhaustive representatives of the actual performance indicators and risk factors respectively poses some limitations. Besides, the choice of the five banks used in this study was largely influenced by the availability and accessibility of their annual financial statements for the period studied. The inability of the researcher to include other banks in the study owing to non-availability of their financial reports for some of the period investigated poses some limitation because of incomplete randomization in the choice of banks.

The above limitations indicate the need for further studies to include some other performance and risk variables. Of particular importance is the need to enlarge the scope by including more banks in order to find out whether there will be any significant deviation from the results of this study.

\subsection{Recommendations}

In view of the problem definition and research findings, it is suggested that strategic managers in banks take risk management as a priority, especially liquidity, leverage, and credit risks. They should be mindful of the short-run and long-run influence of liquidity risk on financial performance. Effective management of risks will enhance their performance and hence their ability to properly manage their assets and equity shareholders. Furthermore, policymakers in government should formulate economic and financial policies with due cognisance of factors that can affect a bank's performance. This requires a holistic view to policy formulation to ensure that cost trade-offs are considerably minimized in all strata of the economy. Specifically, macroeconomic policies that impact on banks' performance, especially interest and inflation rates should be formulated with the interest of the banks and other financial institutions in mind.

\section{References}

Adeusi, S. O., Akeke, N. I., Adebisi, O. S., \& Oladunjoye, O. (2013). Risk management and financial performance of banks in Nigeria. Journal of Business and Management, 14(6), 52-56.

Agbeja, O., Adelakun, O. J., \& Olufemi, F. I. (2015). Capital adequacy ratio and bank profitability in Nigeria: A linear approach. International Journal of Novel Research in Marketing Management and Economics, 2(3), 91-99. 
Akinselure, O. P., \& Akinola, T. A. (2019). Impact of credit risk management on profitability of selected deposit money banks in Nigeria. International Journal of Economics, Commerce and Management, 7(9), 254-268.

Allen, F., \& Carletti, E. (2012). Systemic risk and macro prudential regulation, Chapter 13 in the global macro economy and finance. In F. Allen, M. Aoki, J. Fitoussi, R. Gordon, N. Kiyotaki, \& J. Stiglitz (Eds.), IEA Conference (Volume 150-III). London: Palgrave Macmillan.

Alshatti, A. S. (2015). The effect of credit risk management on financial performance in Jordanian Commercial banks. Investment Management and Financial Innovation, 12(1), 338-345.

Arnold. (2008). Corporate financial management. New Jersey: Financial Times/Prentice Hall.

BGL. (2010). BGL Banking Report, January.

Bhunia, A., Mukhuti, S. S., \& Roy, S, G. (2011). Financial performance analysis: A case study. Current Research Journal of Social Sciences, 3(3), 269-275.

Cardinal Stone. (2016). Research, company filings. Retrieved from https://www.cardinalstone.com/finance/downloads/research_publications/CardinalStone\%20Research\%20-\%20 Zenith\%20Bank\%20Company\%20Report\%20-\%20Building\%20on\%20Leverage \%20-\%20Brand\%20and\%20C apital.pdf

Chukwunulu, J. I., Ezeabasili, V. N., \& Igbodika, M. N. (2019). Impact of credit risk management on the performance of commercial banks in Nigeria (1994-2016). International Journal of Banking and Finance Research, 5(1), 64-71.

Cumming, C., \& Mirtle, B. (2001). The challenges of risk management in diversified financial institutions, Federal Reserve Bank of New York. Economic Policy Review, 7, 1-17.

Engle, R. F., \& Granger, C. W. F. (1987). Cointegration and error correction: Representation, estimation, and testing. Econometrics, 55(2), 251-276.

Etale, L. M., \& Ujuju, L. E. (2018). Risk management, risk concentration, and the performance of deposit money banks in Nigeria. International Journal of Business and Management Review, 6(10), 56-68.

Ezelibe, C. P., \& Aniefor, S. J. (2017). Financial risk management and corporate performance of deposit money banks in Nigeria. Archives of Business Research, 5(12), 78-87.

FBN Holdings. (2017). Financial reports. Retrieved from http://investadvocate.com.ng/2017/04/28/fbnh-reports-gross-earnings-n581-8-billion-15-7-year-year/

Gerrit, J. B. (2008). Strategic risk: Can it be measured? Finecs business consulting. Retrieved from www.financeventures.nl/index.php?type=download\&

Inegbedion, H. E., \& Obadiaru, E. D. (2018). Modelling brand loyalty in the Nigerian telecommunication industry. Journal of Strategic Marketing. https://doi.org/10.1080/0965254X.2018.1462842

Inegbedion, H. E., Obadiaru, E. D., \& Adeyemi, S. O. (2020). Stock prices reaction to oil price Fluctuations: Empirical evidence from Nigeria. International Journal of Energy Economics and Policy, 10(5), 142-149

Ironkwe, U. I., \& Osaat, A. S. (2019). Risk asset management and financial performance of insurance companies in Nigeria. International Journal of Advanced Academic Research, 5(4), 18-46.

Iyoha, M. A., \& Ekanem, O. T. (2004). Introductory econometrics. Mareh Publishers, Benin City.

Kegninkeu, F. T. (2018). The impact of credit risk management on the performance of commercial banks in Cameroon: Case study of BICEC Cameroon. Global Journal of Management and Business Research, 18(7), $18-40$.

Kolapo, T. F., Ayeni, R. K., \& Oke, M. O. (2012). Credit risk and commercial banks' performance in Nigeria: A panel model approach. Australian Journal of Business and Management Research, 2(2), 31-38.

Lasisi, I. O., Lateef, O. M., Irom, M. I., \& Bulus, M. E. (2018). Corporate board size, risk management, and financial performance of listed deposit money banks in Nigeria. European Journal of Accounting, Auditing and Finance Research, 6(1), 1-20.

Mankiw, G. N. (2008). Principles of economics. NY: Cengage Learning.

Miccolis, J., \& Shaw, S. (2000). Enterprise risk management: An analytic approach. Tillinghast- Towers Perrin, New York. 
Miller, K. D. (1992). A framework for integrated risk management in international business. Journal of International Business Studies, 23, 311-331.

Misker, B. (2015). The impact of credit risk on financial performance of banks in Ethiopia. A thesis, Department of Accounting and Finance, College of Business and Economics Addis Ababa University, Ethiopia.

Nocco, B. W., \& Stulz, R. M. (2006). Enterprise risk management: Theory and practice. Journal of Applied Corporate Finance, 18, 8-20.

Nwude, E. C., \& Okeke, C. (2018). Impact of credit risk management on the performance of selected Nigerian banks; International Journal of Economic and Financial Issues, 8(2), 287-297.

Obalola, M. A., Akpan, T. I., \& Abass, O. A. (2014). The relationship between enterprise risk management (ERM) and organizational performance: Evidence from Nigerian insurance industry. Research Journal of Finance and Accounting, 5(14), 152-160.

Ogden, J. P., Jen, F. C., \& O'Connor, P. F. (2002). Advanced corporate finance. New Jersey: Prentice Hall.

Okere, W., Isiaka, M., \& Ogunlowore, A. (2018). Risk management and financial performance of deposit money banks in Nigeria. European Journal of Business, Economics and Accountancy, 6(2), 30-43.

Olajide S. F., \& Fadun, O. (2017). Corporate governance, a risk management tool for enhancing organizational performance: Study of Nigeria Stock Exchange (NSE) listed companies. International Journal of Finance \& Banking Studies.

Olalere, O. E., \& Wan, A. B. (2016). Risk management and the financial performance of commercial banks in Nigeria: A literature review revisited. Journal of Economics and Finance, 7(2), 14-19.

Olokoyo, F. O. (2011). Determinants of commercial banks' lending behaviour in Nigeria. International Journal of Financial Research, 2(2), 60-72.

Olusanmi, O., Uwuigbe, U., \& Uwuigbe, O. R. (2015). The effect of risk management on bank's financial performance in Nigeria. Journal of Accounting and Auditing: Research \& Practice. https://doi.org/10.5171/2015.239854

Osayeme, R. K. (2000). Practice of banking. Lagos: F \& A publisher Ltd, Lagos.

Owojori, A. A., Akintoye I. R., \& Adidu, F. A. (2011). The challenge of risk management in Nigerian banks in the post consolidation era. Journal of Accounting and Taxation, 13(2).

Oyewo, B. M. (2014). Risk asset management and Banks' performance: an empirical examination of relationship using evidences from the Nigerian Banking industry. Journal of Research in National Development, 12(1).

Parlia, D., \& Porter, R. (2007). Agency theory in banking: an empirical analysis of moral hazard and the agency costs of equity. Banks and Bank Systems, 2(3), 142-156.

Salas, V., \& Saurina, J. (2002). Credit risk in two institutional regimes: Spanish commercial and savings banks. Journal of Financial Services Research, 22(3), 76-85.

Trivedi, S. M. (2010). Financial performance analysis. Retrieved from ttp://shodhganga.inflibnet.ac.in/bitstream/10603/705/11/12_chapter3.pdf

Trussel, M. J., \& Patrick, A. P. (2009). An empirical analysis of financial distress in Pennsylvania Hospitals. Journal of Health Care Finance, 36(1), 31-60.

Uwuigbe, U., Uwuigbe, O. R., \& Oyewo, B. (2015). Credit management and banks' performance of listed banks in Nigeria. Journal of Economics and Sustainable Development, 6(2), 27-32.

Vadova, P. (2005). Credit risk as a cause of banking crisis, an unpublished PhD Thesis. Silesian University, school of business administration, department of finance, Univerzitní nám. 76733 40, Karviná Czech Republic.

Table 5. Financial ratios of the banks studied (Access, diamond, GTB, first and zenith)

\begin{tabular}{|c|c|c|c|c|c|c|c|c|c|}
\hline $\mathrm{S} / \mathrm{N}$ & & Year & LDR & $\begin{array}{l}\mathrm{CR} \\
30\end{array}$ & CAR & NPLR & DBTR & ROE & ROA \\
\hline 1 & ACCESS & 2010 & 87.5 & 36.9 & 26.5 & & & 10 & 1.79 \\
\hline & & 2011 & 46.2 & 31 & 22 & 9 & & 7.9 & 1.0 \\
\hline & & 2012 & 47 & 27.8 & 20.6 & 5.3 & & 20.7 & 2.7 \\
\hline
\end{tabular}




\begin{tabular}{|c|c|c|c|c|c|c|c|c|}
\hline & & 2013 & 57.8 & 41.4 & 19.2 & 2.7 & 14.8 & 2.4 \\
\hline & & 2014 & 71.4 & 36 & 18.4 & 2.2 & 16.5 & 2.6 \\
\hline & & 2015 & 80.2 & 44 & 18 & 1.7 & 20.4 & 2.8 \\
\hline & & 2016 & 71.9 & 39 & 19.0 & 2.1 & 17.8 & 2.4 \\
\hline & & 2017 & 72.8 & 46 & 20.5 & 2.5 & 15.7 & 2.1 \\
\hline 2 & Diamond & 2010 & 77.04 & 41.33 & 15.5 & 13.7 & -0.24 & -0.05 \\
\hline & & 2011 & 54.33 & 33.32 & 16 & 12.38 & -30.1 & -3.54 \\
\hline & & 2012 & 67.1 & 42.3 & 17.5 & 4.7 & 22.7 & -0.65 \\
\hline & & 2013 & 59.6 & 41.8 & 18 & 3.5 & 23 & 2.2 \\
\hline & & 2014 & 55.6 & 42 & 18.4 & 5.1 & 14.7 & 1.3 \\
\hline & & 2015 & 63.19 & 34.34 & 16.4 & 6.9 & 2.7 & 0.3 \\
\hline & & 2016 & 71,70 & 32.12 & 15 & 9.5 & 1.6 & 0.14 \\
\hline & & 2017 & 70.86 & 40.2 & 15.1 & 10.3 & 8.4 & 0.052 \\
\hline 3 & GTB & 2010 & 77.54 & 56.12 & 23.24 & 6.15 & 18.93 & 3.5 \\
\hline & & 2011 & 66.49 & 52.66 & 20.68 & 3.14 & 22.78 & 3.73 \\
\hline & & 1012 & 74.35 & 43.83 & 21.56 & 3.19 & 37.48 & 5.69 \\
\hline & & 2013 & 69.87 & 50.31 & 23.91 & 3.58 & 29.32 & 4.69 \\
\hline & & 2014 & 77.67 & 40.07 & 21.40 & 3.15 & 27.93 & 4.43 \\
\hline & & 2015 & 85.28 & 41 & 19.79 & 3.2 & 25.1 & 4.1 \\
\hline & & 2016 & 75.3 & 42.2 & 19.8 & 3.7 & 26.6 & 4.7 \\
\hline & & 2017 & 67.5 & 47.6 & 25.7 & 7.7 & 27.60 & 5.3 \\
\hline 4 & FirstBank & 2010 & 74.1 & 55.4 & 17.0 & 5.8 & 14.1 & 1.96 \\
\hline & & 2011 & 65.9 & 61 & 20.4 & 2.6 & 5.5 & 0.7 \\
\hline & & 2012 & 66 & 44 & 21.4 & 2.6 & 18.9 & 2.5 \\
\hline & & 2013 & 61.9 & 48 & 19.6 & 3.0 & 17.1 & 2.0. \\
\hline & & 2014 & 64 & 53 & 16.7 & 1.7 & 20.2 & 2.2 \\
\hline & & 2015 & 77.1 & 58.6 & 17.1 & 11 & 7.98 & 1.1 \\
\hline & & 2016 & 65.9 & 52.7 & 17.8 & 24.4 & 5.42 & 0.74 \\
\hline & & 2017 & 66.1 & 81 & 18.5 & 22.5 & 8.7 & -5.32 \\
\hline 5 & Zenith & 2010 & 56.8 & 64 & 34 & 5.93 & 10.7 & 2.1 \\
\hline & & 2011 & 54 & 59 & 36 & 3.99 & 12.9 & 2.3 \\
\hline & & 2012 & 51.3 & 61 & 29 & 3.2 & 23.7 & 4.1 \\
\hline & & 2013 & 56.6 & 64 & 31 & 2.91 & 19.6 & 3.3 \\
\hline & & 2014 & 51.8 & 42.9 & 21.6 & 3.1 & 19.0 & 3.0 \\
\hline & & 2015 & $67.2 \%$ & $51.4 \%$ & $21 \%$ & $3.2 \%$ & $20.6 \%$ & $3.2 \%$ \\
\hline & & 2016 & $67.8 \%$ & $59.6 \%$ & $23 \%$ & $3.02 \%$ & $20 \%$ & $3 \%$ \\
\hline & & 2017 & $60.5 \%$ & $69.7 \%$ & $27 \%$ & $4.7 \%$ & $23.3 \%$ & $3.0 \%$ \\
\hline
\end{tabular}

\section{Copyrights}

Copyright for this article is retained by the author(s), with first publication rights granted to the journal.

This is an open-access article distributed under the terms and conditions of the Creative Commons Attribution license (http://creativecommons.org/licenses/by/4.0/). 